Article

\title{
PKC-Mediated Modulation of Astrocyte SNAT3 Glutamine Transporter Function at Synapses in Situ
}

\author{
Wuxing Dong ${ }^{1}$, Alison C. Todd ${ }^{1,2} \mathbb{E}^{\mathbb{C}}$, Angelika Bröer ${ }^{3}$, Sarah R. Hulme ${ }^{1}$, Stefan Bröer ${ }^{3}$ and \\ Brian Billups ${ }^{1, *}$ (iD) \\ 1 Eccles Institute of Neuroscience, The John Curtin School of Medical Research, The Australian National \\ University, 131 Garran Road, Canberra ACT 2601, Australia; dominicdongwuxing@gmail.com (W.D.); \\ s1583068@sms.ed.ac.uk (A.C.T.); sarah.hulme@anu.edu.au (S.R.H.) \\ 2 Centre for Discovery Brain Sciences, School of Biomedical Sciences, University of Edinburgh, \\ Edinburgh EH8 9XD, UK \\ 3 Research School of Biology, The Australian National University, Linnaeus Way 134, Canberra ACT 2601, \\ Australia; angelika.broer@anu.edu.au (A.B.); stefan.broeer@anu.edu.au (S.B.) \\ * Correspondence: brian.billups@anu.edu.au; Tel.: +61-2-612-52039
}

Received: 23 January 2018; Accepted: 15 March 2018; Published: 21 March 2018

\begin{abstract}
Astrocytes are glial cells that have an intimate physical and functional association with synapses in the brain. One of their main roles is to recycle the neurotransmitters glutamate and gamma-aminobutyric acid (GABA), as a component of the glutamate/GABA-glutamine cycle. They perform this function by sequestering neurotransmitters and releasing glutamine via the neutral amino acid transporter SNAT3. In this way, astrocytes regulate the availability of neurotransmitters and subsequently influence synaptic function. Since many plasma membrane transporters are regulated by protein kinase $C$ (PKC), the aim of this study was to understand how PKC influences SNAT3 glutamine transport in astrocytes located immediately adjacent to synapses. We studied SNAT3 transport by whole-cell patch-clamping and fluorescence $\mathrm{pH}$ imaging of single astrocytes in acutely isolated brainstem slices, adjacent to the calyx of the Held synapse. Activation of SNAT3-mediated glutamine transport in these astrocytes was reduced to $77 \pm 6 \%$ when PKC was activated with phorbol 12-myristate 13-acetate (PMA). This effect was very rapid (within 20 min) and eliminated by application of bisindolylmaleimide I (Bis I) or 7-hydroxystaurosporine (UCN-01), suggesting that activation of conventional isoforms of PKC reduces SNAT3 function. In addition, cell surface biotinylation experiments in these brain slices show that the amount of SNAT3 in the plasma membrane is reduced by a comparable amount (to $68 \pm 5 \%$ ) upon activation of PKC. This indicates a role for PKC in dynamically controlling the trafficking of SNAT3 transporters in astrocytes in situ. These data demonstrate that PKC rapidly regulates the astrocytic glutamine release mechanism, which would influence the glutamine availability for adjacent synapses and control levels of neurotransmission.
\end{abstract}

Keywords: Slc38a3; system N; protein kinase C; phorbol ester; protein trafficking; phosphorylation; biotinylation; glia; calyx of Held

\section{Introduction}

Throughout the body, the neutral amino acid glutamine plays a central role in tissue nitrogen homeostasis and intercellular nutrition [1]. In the central nervous system, it is also critically involved in neurotransmitter recycling and metabolism. At synapses, the principal excitatory neurotransmitter glutamate is released to activate postsynaptic cells and is subsequently sequestered into neighbouring astrocytes to terminate the neurotransmitter signal [2]. In these astrocytes, glutamate is amidated to 
form glutamine, which is then transported out of astrocytes and back into neurons for hydrolysis back to glutamate, forming the glutamate-glutamine cycle (see reviews by [3-6]). This cycle is vital for maintaining the supply of presynaptic glutamate and sustaining synaptic communication [7-11]. Similarly, as the brain's main inhibitory neurotransmitter GABA is synthesised from glutamate, glutamine shuttling from astrocytes to neurons is also important for the maintenance of inhibitory neurotransmission [12-15].

Release of glutamine by astrocytes is mediated by Sodium-Neutral Amino Acid Transporter SNAT3 (also known as SN1), the product of the gene Slc38a3, which is a member of the system $\mathrm{N}$ family of neutral amino acid transporters [16]. Amino acid transport by SNAT3 is coupled to the co-transport of one $\mathrm{Na}^{+}$and the counter transport of an $\mathrm{H}^{+}$, resulting in an electroneutral transport process that is close to thermodynamic equilibrium under physiological conditions, and hence it can mediate transport of glutamine either into or out of cells [17-19]. Glutamine is the most abundant amino acid in the brain extracellular fluid and is therefore the major substrate for SNAT3 [20-22], although other neutral amino acids are also transported, including histidine and asparagine [19,23]. SNAT3 is found in a number of tissues, but predominantly in the liver, kidney and brain. Consequently, mice deficient in SNAT3 exhibit several characteristics including hypoglycaemia, ataxia, and growth restriction, which highlight its essential role in metabolic function [24]. In the brain, SNAT3 is localised to astrocytes surrounding synapses and is absent from neurons $[25,26]$. Due to its role in releasing glutamine that is used to maintain glutamatergic and GABAergic neurotransmission, the mechanisms which determine the cell surface expression of SNAT3 in astrocytes are of particular interest.

Dynamic trafficking of transporters in and out of the plasma membrane has been demonstrated for glutamate, GABA, glycine, dopamine, noradrenaline and serotonin transporters [27,28]. A common mechanism in controlling this trafficking is activation of protein kinase $C$ (PKC) [29]. PKC exists in several isoforms that can be categorised as conventional, requiring diacylglycerol (DAG) and calcium for activation (PKC $\alpha, P K C \beta I, P K C \beta I I$ and PKC $\gamma$ ); novel, which are activated by DAG but not calcium (PKC $\delta, P K C \varepsilon, P K C \eta$ and $\mathrm{PKC} \theta$ ); and atypical, which are not activated by DAG or calcium (PKC $\zeta$ and $\mathrm{PKCl} / \lambda$ ) [30]. Astrocytes in situ express a number of these different PKC isoforms, including PKC $\alpha$, PKC $\beta I, P K C \beta I I$ and PKC $\delta$ [31-35] and a variety of G-protein-coupled membrane receptors that can activate them [36]. The SNAT3 amino acid sequence contains a several consensus sequences for PKC phosphorylation $[37,38]$, and previous studies in Xenopus oocytes and cultured cells have demonstrated that activation of PKC causes SNAT3 internalisation, possibly involving its phosphorylation [37-40]. However, expression of different PKC isoforms is tissue specific [41] and astrocytes express different isoforms than, for example, glioma cells or cultured glia at different stages of differentiation [42-45]. It is thus hard to infer the effects of PKC activation of SNAT3 in vivo from studies of cultured cells, and hence, the aim of this study is to investigate the effects of PKC activation on SNAT3 function and trafficking in astrocytes in situ, using acutely isolated brain slices. These astrocytes maintain their close relationship with pre- and postsynaptic neurons in an environment that closely mimics the true in vivo situation.

We have studied SNAT3 transporter function in astrocytes located immediately adjacent to the calyx of Held synapse in brain slices from the auditory brainstem of rats and mice. The calyx of Held is a large glutamatergic presynaptic terminal that can be visually identified in brain slices [46]. Astrocytes are in close association with this synapse [47] and heavily express SNAT3 [25]. This synapse is a pertinent model of neurotransmitter recycling because of its high neurotransmitter turnover [10]. We have previously shown that astrocytes adjacent to the calyx of Held play a central role in regulating neurotransmission by sequestering glutamate and releasing glutamine (via SNAT3) to maintain the presynaptic neurotransmitter supply $[9,48,49]$. Here, we show that activation of PKC rapidly reduces SNAT3 function at synapses by dynamic internalisation of transporters from the astrocytic plasma membrane, which will play an important role in regulating neurotransmitter supply in the central nervous system. 


\section{Results}

\subsection{Astrocytic SNAT3 Glutamine Transport in Acutely Isolated Brain Slices}

To measure SNAT3 activity in individual brain astrocytes we examined astrocytes in brainstem slices from acutely isolated rat brains. Astrocytes immediately adjacent to principal neurons of the medial nucleus of the trapezoid body (MNTB) were whole-cell voltage-clamped and dialysed with the cell-impermeant fluorescent $\mathrm{pH}$ indicator HPTS (Figure 1a). Astrocytes were positively identified by the morphology visible under fluorescent illumination, showing a characteristic branching structure and close association with the calyx of Held synapse around the MNTB cell soma (Figure 1b). The cells also had electrical properties characteristic of astrocytes, showing no significant voltage activated currents over a range of voltage steps, a low membrane resistance and a resting membrane potential of around $-80 \mathrm{mV}$ (Figure 1c). SNAT3 glutamine transport was activated by pressure ejection of $10 \mathrm{mM}$ glutamine from a puffer pipette placed $20-50 \mu \mathrm{m}$ from the astrocyte soma (Figure 1a). This was performed in a cocktail of antagonists and ion channel inhibitors to prevent artefactual activation of glutamate receptors, GABA receptors, glycine receptors, sodium channels or potassium channels. As SNAT3 mediated glutamine transport is powered by the co-transport of $\mathrm{Na}^{+}$and the counter transport of $\mathrm{H}^{+}$, it is electroneutral. However, it can be visualised by the intracellular alkalinisation observed upon glutamine application (Figure 1di), as we have previously demonstrated [9]. This response is positively identified as solely SNAT3-mediated by the affinity for glutamine, specificity for a range of amino acid substrates and lithium tolerance [9].

\subsection{SNAT3 Function is Reduced by PKC Activation}

Under control conditions, $5 \mathrm{~s}$ puff application of $10 \mathrm{mM}$ glutamine, repeated every 2 min, results in a consistent SNAT3-mediated alkalinisation of $0.06 \pm 0.01 \mathrm{pH}$ units $(n=5)$. Following a period of baseline recording (>10 $\mathrm{min}$ ), $400 \mathrm{nM}$ PMA was added to the perfusing bath solution, to activate PKC. After 20 min of PMA application, the glutamine-induced alkalinisation in the same cells was reduced to $77 \pm 6 \%$ of the original response (Figure 1di,e; $p=0.005$ compared to baseline). In contrast, when no PMA was added to the bath, the degree of SNAT3 activation in each cell remained stable for the duration of the recording. Using the same time protocol as for PMA application, an average of $10 \mathrm{~min}$ of responses following incubation with control aCSF for $20 \mathrm{~min}$ was compared to the average of $10 \mathrm{~min}$ of recording prior to aCSF incubation. No significant change in SNAT3 activity was observed under these control conditions (Figure 1dii,e; $112 \pm 5 \% ; n=3 ; p=0.07$ ), demonstrating the PMA-induced reduction of SNAT3 activity was not due to a time dependent run-down and likely represents the effect of PKC activation ( $p=0.004$ for the PMA effect compared to 20 min aCSF incubation). 


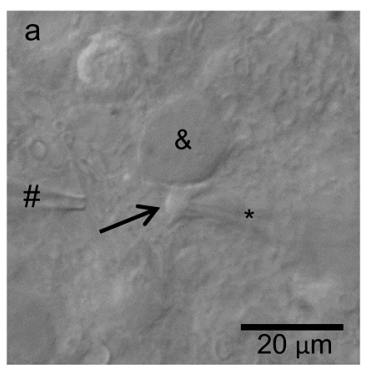

d

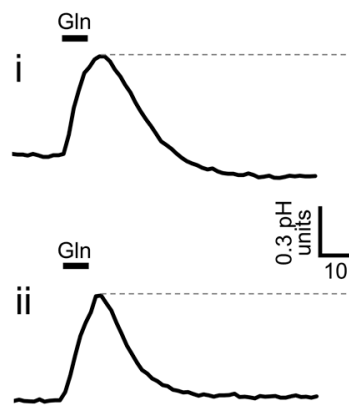

Baseline



Gln



Gln

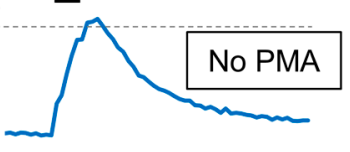

After 20 min incubation



e



Figure 1. PKC activation reduces SNAT3 function. (a) Differential interference contrast image of a rat brainstem slice showing an astrocyte (arrow) adjacent to an MNTB principal neuron (\&). The astrocyte is whole-cell voltage-clamped with a patch-pipette $(*)$, and a puffer pipette (\#) is visible near-by; (b) The same astrocyte visualised by excitation of the internal HPTS dye using $465 \mathrm{~nm}$ light. Astrocyte processes can be seen wrapping around the MNTB neuron; (c) Current responses in a voltage-clamped astrocyte to $50 \mathrm{~ms}$ voltage steps from a holding potential of $-80 \mathrm{mV}$ (inset). The current-voltage relationship is shown for $10 \mathrm{mV}$ steps from -160 to $+40 \mathrm{mV}$; (d) Example fluorescence recording of intracellular $\mathrm{pH}$ in a rat astrocyte as $10 \mathrm{mM}$ glutamine is puff-applied for $5 \mathrm{~s}$ (black bars). In one cell (d) $\mathbf{i}$ initial baseline responses recorded for $10 \mathrm{~min}$ (black trace) are compared to responses after $20 \mathrm{~min}$ bath application of $400 \mathrm{nM}$ PMA (red trace). A different cell (d) ii shows a consistent $\mathrm{pH}$ response at the beginning (black trace) and end of the recording (blue trace) when no PMA is added; (e) Averaged data from 5 rat cells show a glutamine induced alkalinisation of $0.058 \pm 0.009 \mathrm{pH}$ units $(n=5)$ at the beginning of recording, compared to $0.045 \pm 0.007 \mathrm{pH}$ units $(n=5)$ after 20 min PMA application (red bar; ${ }^{*} p$ <.01). Control data shows that incubation in PMA-free solution has no effect over the same time period $(0.071 \pm 0.004 \mathrm{pH}$ units at baseline vs. $0.080 \pm 0.005 \mathrm{pH}$ units after incubation in artificial cerebrospinal fluid (aCSF); blue bar; $n=3$ ). The values of each cell are shown by the individual points and represent an average of responses over $10 \mathrm{~min}$ recording in baseline, compared to an average of 10 min recording following 20 min of PMA or aCSF bath incubation.

\subsection{Conventional PKC Isoforms Inhibit SNAT3 Function}

Recording SNAT3 function in astrocytes for the long time periods used in Figure 1 was exceptionally difficult, and good statistical power was hard to achieve with this technique. Therefore, to confirm the effects of PKC activation on SNAT3 activity, and to investigate the PKC isoforms mediating the reduction of SNAT3 function, we incubated slices in PMA and pharmacological antagonists for $1 \mathrm{~h}$ before beginning recording. Under these conditions, comparing SNAT3 function between different cells in different brain slices, it was observed that PMA incubation induced an almost identical effect to applying PMA during recordings. Under control conditions the SNAT3-mediated alkalinisation was $0.064 \pm 0.003 \mathrm{pH}$ units $(n=24)$, which was reduced to $0.048 \pm 0.005 \mathrm{pH}$ units (to $75.0 \pm 8.6 \%$ ) by incubation in $100 \mathrm{nM}$ PMA (Figure $2 \mathrm{a} ; n=7 ; p=0.021$ ). In the presence of bisindolylmaleimide I (Bis I) to inhibit PKC activation, the SNAT3 induced cellular alkalinisation was unchanged by incubation with PMA (Figure 2a; $p=0.80$ ). Similarly, incubation with UCN-01, 
a selective inhibitor of conventional PKC isoforms [50], also prevented the effect of PMA on SNAT3 (Figure $2 \mathrm{~b} ; p=0.32$ ), suggesting that PKC $\alpha$, PKC $\beta I, P K C \beta I I$ or PKC $\gamma$ mediate inhibition of SNAT3.

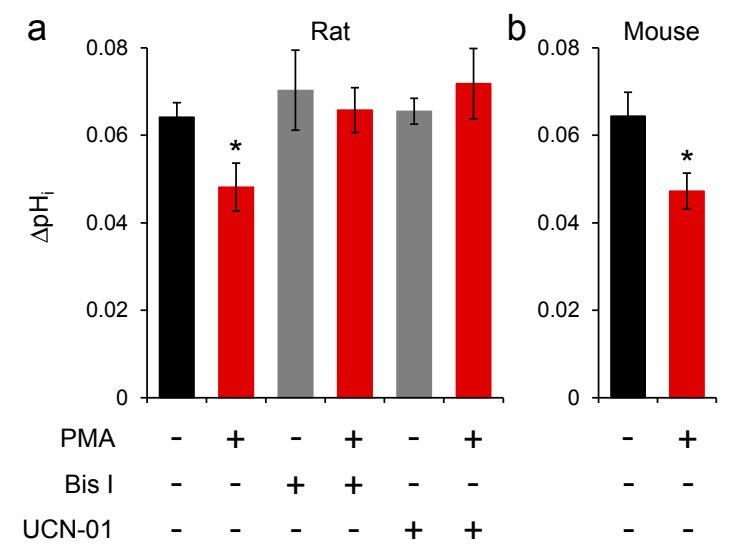

Figure 2. Conventional PKC isoforms reduce SNAT3 function. (a) Glutamine-induced alkalinisations in rat astrocytes, recorded after pre-incubation of slices in PMA or pharmacological analogues. $1 \mathrm{~h}$ incubation with $100 \mathrm{nM}$ PMA reduces the SNAT3-meidated alkalinisation to $0.048 \pm 0.005 \mathrm{pH}$ units $\left(n=7 ;{ }^{*} p<0.05\right) .100 \mathrm{nM}$ Bis I does not affect the SNAT3 function $(0.070 \pm 0.009 \mathrm{pH}$ units; $n=7$; $p=0.36)$ but does inhibit the action of PMA $(0.066 \pm 0.005 \mathrm{pH}$ units; $n=7 ; p=0.78)$. $10 \mathrm{nM} \mathrm{UCN}-01$ also does not affect SNAT3 function $(0.065 \pm 0.003 \mathrm{pH}$ units; $n=5 ; p=0.86)$ but inhibits PMA action $(0.071 \pm 0.008 \mathrm{pH}$ units; $n=5 ; p=0.32)$; (b) Glutamine-induced alkalinisation in mouse astrocytes, similarly incubated for $1 \mathrm{~h}$ in control or $100 \mathrm{nM}$ PMA containing solution. PMA induces a reduction in SNAT3-mediated alkalinisation to $0.047 \pm 0.004 \mathrm{pH}$ units $\left(n=13 ;{ }^{*} p<0.05\right)$.

\subsection{PKC Inhibition of Mouse SNAT3 Function}

All previous experiments we performed on rat brain slices, so to validate our results in mice we also performed a series of experiments in mouse astrocytes from the same brain area. The control SNAT3-induced alkalinisation was identical to that observed in rats, with $10 \mathrm{mM}$ glutamine application inducing a $\mathrm{pH}$ change of $0.064 \pm 0.005 \mathrm{pH}$ units $(n=11)$. Similar to rats, incubation of mouse slices in PMA reduced the SNAT3-induced $\mathrm{pH}$ change to $0.047 \pm 0.004 \mathrm{pH}$ units (to $73.4 \pm 6.3 \%$; $n=13$; Figure $2 \mathrm{~b} ; p=0.017$ ).

\subsection{PKC Activation Induces Internalisation of SNAT3}

The reduction in SNAT3 function by PMA could be due to the inhibition of transporter action or removal of transporters from the plasma membrane. Since PKC activation has been shown to induce the internalisation of a number of different classes of membrane transporters, we tested the hypothesis that activating PKC internalises SNAT3. We have previously demonstrated PKC induced internalisation of SNAT3 in Xenopus oocytes using biotinylation of surface proteins and immunohistochemistry [37]. We have applied the same technique here, using biotinylation of individual brain slices of rat MNTB, followed by detection of SNAT3 using western blotting with a SNAT3 antibody. One-hour pre-incubation of slices in $100 \mathrm{nM}$ PMA resulted in a reduction in the surface expression of SNAT3 compared to control slices, which was not observed when slices were incubated with the inactive control compound $4 \alpha$-PMA (Figure 3a). Quantification from repeat experiments showed that PKC activation with PMA induced a reduction of SNAT3 surface expression to $67.8 \pm 4.6 \%$ of control (Figure $3 \mathrm{~b} ; n=6 ; p=0.014$ ). In comparison, $4 \alpha$-PMA had no effect on SNAT3 surface expression (Figure 3b; $116 \pm 10 \% ; n=4 ; p=0.30$ ). These data demonstrate that PMA induces internalisation of SNAT3 from the astrocyte plasma membrane in acutely isolated brain slices. 
a

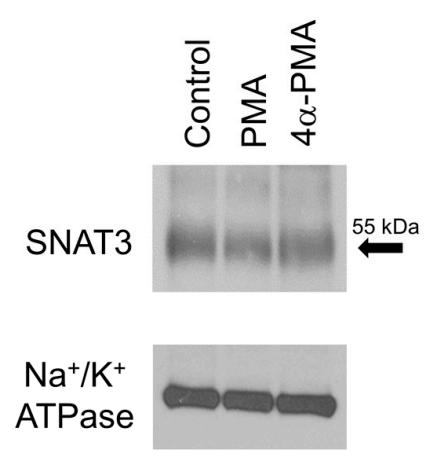

b

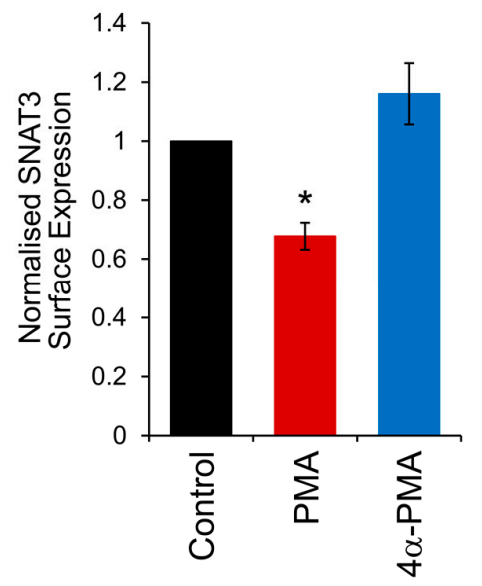

Figure 3. PKC activation internalises SNAT3. (a) A representative blot showing surface biotinylation of rat SNAT3 shown by western blot analysis. Slices were treated for $1 \mathrm{~h}$ in control, $100 \mathrm{nM}$ PMA or $100 \mathrm{nM} 4 \alpha$-PMA prior to fixation and biotinylation. The SNAT3 surface expression is indicated by the band at $55 \mathrm{kDa}$ (arrow, top panel). The gel loading control against the $\mathrm{Na}^{+} / \mathrm{K}^{+}$-ATPase is shown in the lower panel; (b) Quantification from 6 separate experiments shows a significant reduction of rat SNAT3 surface expression by incubation in $100 \mathrm{nM}$ PMA (red bar; $n=6$; ${ }^{*} p<0.05$ ), whereas the $4 \alpha$-PMA control did not show an effect (blue bar; $n=4 ; p=0.30$ ).

\section{Discussion}

Our data show that the function of SNAT3 in astrocytes adjacent to synapses is rapidly downregulated by the activation of PKC. The degree of downregulation is mirrored by the proportion of transporters that are internalised upon PKC activation, indicating that the reduction in SNAT3 function can be entirely explained by a phosphorylation-mediated trafficking of the transporter from the plasma membrane.

We have used two separate approaches to investigate SNAT3 downregulation: recordings from individual cells in brain slices and measuring internalization in whole-tissue lysates. This combination greatly enhances our ability to draw firm conclusions from our data. For example, PKC activation by PMA may affect a variety of cellular processes, which could cause an artefactual change in the observed $\mathrm{pH}$ signal in Figures 1 and 2, independent of effects on SNAT3 transport. The biotinylation experiment (Figure 3) allows us to discount this possibility, as this technique measures SNAT3 surface expression directly, and shows a clear internalization of the transporter. On the other hand, the whole-tissue lysates used in Figure 3 contain a number of different cell types, not just astrocytes. While SNAT3 in the brain is almost exclusively expressed by astrocytes, and is not observed in neurons or oligodendrocytes $[19,25,26]$, some contamination of the signal by other cell types cannot be totally excluded. However, the single cell recordings (Figures 1 and 2) show SNAT3 downregulation in positively identified individual astrocytes, providing reassurance that the internalization is astrocytic.

PKC-induced internalisation of SNAT3 has previously been clearly demonstrated by our group and others in Xenopus oocytes and cell lines [37,38]. However, studies of cultured astrocytes have revealed inconsistent results. Nissen-Meyer et al. demonstrate that SNAT3 in cultured rat astrocytes is phosphorylated by PKC [38], however Balkrishna et al. show that PKC activation does not affect SNAT3 function in astrocyte cultures [37]. In contrast to the rapid ( 30 $\mathrm{min})$ effects of PKC that we and others observe $[37,38]$, Sidoryk-Wegrzynowicz et al. demonstrate an effect of PKC activation on SNAT3 internalisation in astrocyte cultures that takes $2-4 \mathrm{~h}$ [39]. These diverse effects observed in astrocyte cultures highlight the inadequacies of the culture model for understanding astrocytic function in vivo. For example, cultured astrocytes express significantly reduced amounts of SNAT3 compared to astrocytes in vivo [51], and the profile of PKC isoform expression is altered during differentiation 
of astrocytic cells [43-45]. These observations underscore the importance of our study on astrocytes in situ to understand the true physiological effects of PKC activation on SNAT3 function.

Our pharmacological data indicate that one of the conventional PKC isoforms mediates SNAT3 internalisation; PKC $\alpha$, PKC $\beta I$, PKC $\beta I I$ or PKC $\gamma$. This is consistent with the in vitro phosphorylation of SNAT3 by PKC $\alpha$ or PKC $\gamma$ [38], but indicates a different mechanism occurring in our experiments than the longer-term PKC $\delta$-mediated effects on SNAT3 caused by manganese (II) exposure [39]. Whether direct phosphorylation of SNAT3 protein itself is required for internalisation is a controversial issue. Nissen-Meyer et al. show that in vitro SNAT3 is phosphorylated only at position S52, and that this is required for internalisation of SNAT3 when expressed in oocytes [38]. In contrast, Balkrishna et al. demonstrate that none of the PKC consensus sequences on the SNAT3 protein are required to be phosphorylated to observe a PKC-induced internalisation, and suggest that the target of PKC is elsewhere in the internalisation pathway [37]. In this study we have not directly investigated whether SNAT3 itself is phosphorylated. However, we have observed that both rat and mouse SNAT3 are down-regulated by PKC activation. This is significant because the serine residue present in the putative PKC phosphorylation site at positon 52 in rat is replaced by a proline residue in mouse and humans [38]. Thus, direct phosphorylation at position 52 cannot explain the PKC-mediated effects we observe and suggests that while PKC may possibly phosphorylate SNAT3, it could also affect transporter internalisation by phosphorylating other proteins in the trafficking pathway.

The mechanism of PKC-induced internalisation of SNAT3 has been shown to be caveolin dependent, but independent of dynamin [37]. It is also known that SNAT3 is a target for the ubiquitin ligase Nedd4-2 [39,52,53], which will tag the transporter for internalisation and degradation. As the interaction between Nedd4-2 and SNAT3 is enhanced by PKC activation [39], it is likely that the PKC-mediated internalisation that we observe involves this mechanism.

PKC-mediated internalisation of a wide range of plasma membrane transporters has been reported including transporters for dopamine [54,55], noradrenaline [56,57], serotonin [58], glycine [59,60], GABA [61], neutral amino acids [62] and glutamate [63,64]. Ubiquitination is involved in the internalization of glycine transporters GlyT1 [65] and GlyT2 [66] and the glutamate transporter GLT-1 $[67,68]$. Specifically, Nedd4-2 mediated ubiquitination mediates the internalization of the dopamine transporter DAT [69] and GLT-1 [70-72], suggesting that common trafficking mechanisms exist between SNAT3 and a wide range of other amino acid and biogenic amine transporters. However, it is currently unknown how PKC influences the interaction between Nedd4- 2 and any of these transporters.

What is the physiological function of PKC-mediated regulation of SNAT3? Astrocytes in vivo express a variety of Gq-coupled receptors that can activate PKC (reviewed by [36]). This includes receptors for glutamate (mGluR1 \& 5), acetylcholine $\left(\mathrm{M}_{1}\right)$, noradrenaline $\left(\alpha_{1}\right)$, serotonin $\left(5-\mathrm{HT}_{2 \mathrm{~A}}\right)$, histamine $\left(\mathrm{H}_{1}\right)$, ATP $\left(\mathrm{P}_{2} \mathrm{Y}\right)$, substance $\mathrm{P}$, interleukin-1 beta [73] and neurosteroids $(\sigma 1[74])$. Hence, they are very sensitive to the neuronal activity around them and the subsequent intracellular signalling cascades can adjust the function of their plasma membrane transporters. Amino acid transporters have been shown to be present in intracellular vesicle pools, which are rapidly trafficked in and out of the plasma membrane via exo- and endocytosis mechanisms [7,75]. The control of these processes via Gq-coupled receptor signaling could represent a universal feedback mechanism to regulate cell function. In the case of excitatory synapse, SNAT3 and the astrocytic glutamate transporters (GLT-1 and GLAST) are both located in the same microdomain, adjacent to active synapses $[25,76]$ where they are physically and functionally coupled $[9,77]$. They each play vital roles in controlling synaptic function, with glutamate transporters quickly removing glutamate to terminate the synaptic signal [78] and SNAT3 releasing glutamine for neuronal regeneration of glutamate [7-9]. PKC has similar effects on GLT-1 and SNAT3, causing down-regulation via internalisation with comparably rapid kinetics. Thus, astrocytic PKC signalling represents a central point that can dynamically control the glutamate-glutamine cycle, regulating the supply of neurotransmitter precursors and having a major influence on the efficacy of synaptic transmission. This negative 
feedback system, where activation of adjacent excitatory synapses would trigger suppression of further activity, could be tested experimentally and is an avenue for further study in this field.

\section{Materials and Methods}

\subsection{Brain Slice Preparation}

Wistar rats or C57BL/ 6 mice aged 10 to 15 days, of either sex, were killed by decapitation in accordance with the procedure approved by the Animal Experimentation Ethics Committee of the Australian National University (protocols A2014/59 approved 18 November 2014 and A2017/49 approved 21 November 2017). Brains were swiftly removed and transferred to oxygenated ice cold slicing solution containing (in mM): $2.5 \mathrm{KCl}, 10$ HEPES, $1.25 \mathrm{NaH}_{2} \mathrm{PO}_{4}, 10$ glucose, 290 sucrose, $4 \mathrm{MgCl}_{2}, 0.1 \mathrm{CaCl}_{2}$, and $\mathrm{pH}$ set to 7.3 with $\mathrm{NaOH}$. Transverse brain slices, $100-140 \mu \mathrm{m}$ thick, of the auditory brainstem containing the MNTB were made using an Integraslice 7550 PSDS tissue slicer (Campden Instruments, Loughborough, UK). Slices were placed in an incubation chamber at $37^{\circ} \mathrm{C}$ for 30 min containing $\mathrm{O}_{2}$ bubbled aCSF composed of (in $\mathrm{mM}$ ): $145 \mathrm{NaCl}, 2.5 \mathrm{KCl}, 10 \mathrm{HEPES}, 1.25 \mathrm{NaH}_{2} \mathrm{PO}_{4}$, 10 glucose, $1 \mathrm{MgCl}_{2}, 2 \mathrm{CaCl}_{2}$, with osmolarity of $320 \mathrm{mmol} \cdot \mathrm{kg}^{-1}$ and $\mathrm{pH}$ set to 7.3 with $\sim 4.5 \mathrm{mM}$ $\mathrm{NaOH}$. Following incubation, the chamber and slices were left to rest in aCSF at room temperature and used within $8 \mathrm{~h}$.

\subsection{Electrophysiological Recording}

Patch-clamp electrode and puffer pipettes were pulled from thick-walled borosilicate glass capillaries (GC150F-7.5; Harvard Apparatus, Holliston, MA, USA). Electrodes for astrocyte recordings had open tip resistance of 6-6.5 $\mathrm{M} \Omega$ and were filled with internal solution containing (in $\mathrm{mM}$ ): $130 \mathrm{KCl}, 4$ Glucose, 20 Sucrose, 10 HEPES, 0.1 EGTA, $0.025 \mathrm{CaCl}_{2}, 1.4 \mathrm{MgATP}, 0.6 \mathrm{NaGTP}$, 0.25 8-Hydroxypyrene-1,3,6-trisulfonic acid (HPTS); $\mathrm{pH}$ set to 7.2 by $\mathrm{KOH}$ and osmolarity made up to $305 \mathrm{mmol} \cdot \mathrm{kg}^{-1}$ by the addition of sucrose. During recording brain slices were continually perfused with aCSF (composition as above) at $32-34{ }^{\circ} \mathrm{C}$, at a rate of $1 \mathrm{~mL} \mathrm{~min}{ }^{-1}$, in a solution containing a cocktail of ion channel inhibitors (in $\mu \mathrm{M}$ ): 40 DL-2-amino-5-phospohonopentanoic acid (APV), 10 dizocilpine maleate (MK801), 20 NBQX, 1 tetrodotoxin (TTX), $10 \mathrm{mM}$ tetraethylammonium chloride (TEA), 1 strychnine and 10 bicuculline methochloride. Astrocytes were visualised with infrared differential interference contrast (DIC) optics and voltage-clamped at $-80 \mathrm{mV}$ using a HEKA EPC-10 double amplifier (HEKA Elektronik Dr. Schulze GmbH, Lambrecht/Pfalz, Germany), low-pass filtered at 10 and $2.9 \mathrm{kHz}$, and digitized at $25 \mathrm{kHz}$ with Patchmaster software (HEKA). All chemicals were purchased from Sigma-Aldrich (Castle Hill, NSW, Australia), except APV, bicuculline, MK-801, NBQX (Abcam, Melbourne, VIC, Australia); and TTX (Latoxan, Portes-lès-Valence, France).

\subsection{Fluorescent $p H$ Imaging}

Intracellular $\mathrm{pH}$ was fluorescently imaged by the inclusion of $250 \mu \mathrm{M}$ HPTS in the internal solution. Cells were illuminated at 465 and $405 \mathrm{~nm}$ (100 ms exposure each) using a monochromator (Optoscan, Cairn Research, Faversham, UK). Images were collected, via a $505 \mathrm{~nm}$ dichroic mirror and $520 \mathrm{~nm}$ long-pass filter, with an electron-multiplying CCD camera (Cascade 512B, Photometrics, Tucson, AZ, USA) controlled by MetaFluor software (Molecular Devices, Sunnyvale, CA, USA). The frame rate was one pair of images per second, for a duration of $60 \mathrm{~s}$ per glutamine puff. SNAT3 was activated by a puff of $10 \mathrm{mM}$ glutamine (dissolved in ASCF), pressure ejected from an adjacent pipette using a Picospritzer III (Parker Hannifin, Hollis, NH, USA). Intracellular $\mathrm{pH}$ was calculated from the ratio of fluorescence levels emitted at 465 and $405 \mathrm{~nm}$ after background subtraction [79]. Approximately calibration was performed by constructing a calibration curve using pipette solutions of known $\mathrm{pH}$, which was linear in the range $\mathrm{pH} 6.8$ to 8.6 . 


\subsection{Surface Biotinylation}

To determine plasma membrane expression of SNAT3, brain slices were first incubated for $1 \mathrm{~h}$ at $34{ }^{\circ} \mathrm{C}$ in control aCSF, PMA or $4 \alpha$-PMA solution. Following this, they were washed 3 times with ice cold PBS at pH 8.0. Subsequently, slices were incubated for $30 \mathrm{~min}$ at room temperature in $0.5 \mathrm{mg} / \mathrm{mL}$ sulfo-NHS-LC-Biotin (Pierce, Rockford, IL, USA) in the continued presence of PMA or $4 \alpha$-PMA. Slices were then lysed by incubation in lysis buffer $(150 \mathrm{mM} \mathrm{NaCl}, 20 \mathrm{mM}$ Tris.HCl, $\mathrm{pH} 7.5,1 \%$ Triton X-100) for 30-60 min on ice. The lysate was centrifuged at top speed in a tabletop centrifuge for $15 \mathrm{~min}$ at $4{ }^{\circ} \mathrm{C}$, and the supernatant was mixed with $50 \mu \mathrm{L}$ of streptavidin-coated agarose particles (Pierce). The suspension was incubated at $4^{\circ} \mathrm{C}$ overnight with slight agitation. Agarose particles (approx. $50 \mu \mathrm{L}$ ) were washed 4 times with lysis buffer, and subsequently $20 \mu \mathrm{L}$ 4-times concentrated sample buffer and $8 \mu \mathrm{L}$ of 10-times concentrated reducing agent (Invitrogen, Scoresby, VIC, Australia) was added to the agarose particles to yield a sample volume of $80 \mu \mathrm{L}$. Samples were boiled for $5 \mathrm{~min}$, and an aliquot of $30 \mu \mathrm{L}$ was loaded on the gel.

To detect SNAT3 an affinity-purified custom antibody was used (Pineda Antibody Service, Berlin, Germany). The antiserum was generated in rabbits against protein-coupled peptide EIPRQTEMVELVPNGKHLE. This peptide sequence is unique to SNAT3/Slc38a3 and shows no homology to other Slc38 transporters, including other putative members of system N. The purified antibody was used at a dilution of 1:1000. It detects a band at $55 \mathrm{kDa}$, which can be blocked by the immunogenic peptide. The antibody was tested on HEK293 cells overexpressing rSNAT3/pcDNA3.1+ and resulted in a single $55 \mathrm{kDa}$ band [80]. Antibody binding was detected by enhanced chemiluminescence using the ECL system according to manufacturer's instructions using the provided secondary antibody at a dilution of 1:2000 (Amersham Pharmacia Biotech, Castle Hill, NSW, Australia). Bands on western blots were visualised by $\mathrm{X}$-ray film exposure, with loading controls $\left(\mathrm{Na}^{+}-\mathrm{K}^{+}\right.$-ATPase) visualised on the same blot after stripping and re-exposure. Band intensity was quantified using Image J (version 1.50, National Institutes of Health, Bethesda, MD, USA) and the intensities were normalised to the loading control.

\subsection{Data Analysis}

Results are presented as mean \pm SEM. Stated n-numbers represent observations from individual brain slices. Statistical comparisons were performed using linear mixed effects (LME) ANOVA, implemented in $\mathbf{R}$, and regarded as statistically significant if $p<0.05$.

\section{Conclusions}

Our results show that SNAT3 glutamine transporters in brain astrocytes are internalised by activation of PKC. This occurs in a physiological preparation, and within a brief timescale of a few minutes. As the role of this transporter at synapses is to mediate the shuttling of glutamine from astrocytes to presynaptic terminals for glutamate production, this dynamic regulation by PKC represents a potential mechanism for rapidly modulating the efficacy of synaptic communication.

Acknowledgments: This work is supported by the National Health and Medical Research Council of Australia (grant 1105857 to Brian Billups and Stefan Bröer) and the Australian Research Council (grant DP180101702 to Stefan Bröer and Brian Billups).

Author Contributions: Wuxing Dong, Alison C. Todd, Angelika Bröer, Sarah R. Hulme, Stefan Bröer and Brian Billups conceived and designed the experiments; Wuxing Dong, Alison C. Todd, Angelika Bröer and Sarah R. Hulme performed the experiments; Wuxing Dong, Alison C. Todd, Angelika Bröer and Brian Billups analyzed the data; Brian Billups wrote the paper.

Conflicts of Interest: The authors declare no conflict of interest. 


\section{References}

1. Newsholme, P.; Procopio, J.; Lima, M.M.; Pithon-Curi, T.C.; Curi, R. Glutamine and glutamate-Their central role in cell metabolism and function. Cell Biochem. Funct. 2003, 21, 1-9. [CrossRef] [PubMed]

2. Danbolt, N.C. Glutamate uptake. Prog. Neurobiol. 2001, 65, 1-105. [CrossRef]

3. Bak, L.K.; Schousboe, A.; Waagepetersen, H.S. The glutamate/GABA-glutamine cycle: Aspects of transport, neurotransmitter homeostasis and ammonia transfer. J. Neurochem. 2006, 98, 641-653. [CrossRef] [PubMed]

4. Daikhin, Y.; Yudkoff, M. Compartmentation of brain glutamate metabolism in neurons and glia. J. Nutr. 2000, 130, 1026S-1031S. [CrossRef] [PubMed]

5. Hertz, L.; Dringen, R.; Schousboe, A.; Robinson, S.R. Astrocytes: Glutamate producers for neurons. J. Neurosci. Res. 1999, 57, 417-428. [CrossRef]

6. Rothman, D.L.; Behar, K.L.; Hyder, F.; Shulman, R.G. In vivo NMR studies of the glutamate neurotransmitter flux and neuroenergetics: Implications for brain function. Annu. Rev. Physiol. 2003, 65, 401-427. [CrossRef] [PubMed]

7. Billups, D.; Marx, M.C.; Mela, I.; Billups, B. Inducible presynaptic glutamine transport supports glutamatergic transmission at the calyx of Held synapse. J. Neurosci. 2013, 33, 17429-17434. [CrossRef] [PubMed]

8. Tani, H.; Dulla, C.G.; Farzampour, Z.; Taylor-Weiner, A.; Huguenard, J.R.; Reimer, R.J. A local glutamate-glutamine cycle sustains synaptic excitatory transmitter release. Neuron 2014, 81, 888-900. [CrossRef] [PubMed]

9. Todd, A.C.; Marx, M.C.; Hulme, S.R.; Broer, S.; Billups, B. SNAT3-mediated glutamine transport in perisynaptic astrocytes in situ is regulated by intracellular sodium. Glia 2017, 65, 900-916. [CrossRef] [PubMed]

10. Marx, M.C.; Billups, D.; Billups, B. Maintaining the presynaptic glutamate supply for excitatory neurotransmission. J. Neurosci. Res. 2015, 93, 1031-1044. [CrossRef] [PubMed]

11. Rae, C.; Hare, N.; Bubb, W.A.; McEwan, S.R.; Broer, A.; McQuillan, J.A.; Balcar, V.J.; Conigrave, A.D.; Broer, S. Inhibition of glutamine transport depletes glutamate and GABA neurotransmitter pools: Further evidence for metabolic compartmentation. J. Neurochem. 2003, 85, 503-514. [CrossRef] [PubMed]

12. Fricke, M.N.; Jones-Davis, D.M.; Mathews, G.C. Glutamine uptake by System A transporters maintains neurotransmitter GABA synthesis and inhibitory synaptic transmission. J. Neurochem. 2007, 102, 1895-1904. [CrossRef] [PubMed]

13. Jiang, E.; Yan, X.; Weng, H.R. Glial glutamate transporter and glutamine synthetase regulate GABAergic synaptic strength in the spinal dorsal horn. J. Neurochem. 2012, 121, 526-536. [CrossRef] [PubMed]

14. Liang, S.L.; Carlson, G.C.; Coulter, D.A. Dynamic regulation of synaptic GABA release by the glutamateglutamine cycle in hippocampal area CA1. J. Neurosci. 2006, 26, 8537-8548. [CrossRef] [PubMed]

15. Yang, S.; Cox, C.L. Attenuation of inhibitory synaptic transmission by glial dysfunction in rat thalamus. Synapse 2011, 65, 1298-1308. [CrossRef] [PubMed]

16. Broer, S. The SLC38 family of sodium-amino acid co-transporters. Pflugers Arch. 2014, 466, 155-172. [CrossRef] [PubMed]

17. Broer, A.; Albers, A.; Setiawan, I.; Edwards, R.H.; Chaudhry, F.A.; Lang, F.; Wagner, C.A.; Broer, S. Regulation of the glutamine transporter SN1 by extracellular $\mathrm{pH}$ and intracellular sodium ions. J. Physiol. 2002, 539, 3-14. [CrossRef] [PubMed]

18. Chaudhry, F.A.; Krizaj, D.; Larsson, P.; Reimer, R.J.; Wreden, C.; Storm-Mathisen, J.; Copenhagen, D.; Kavanaugh, M.; Edwards, R.H. Coupled and uncoupled proton movement by amino acid transport system N. EMBO J. 2001, 20, 7041-7051. [CrossRef] [PubMed]

19. Chaudhry, F.A.; Reimer, R.J.; Krizaj, D.; Barber, D.; Storm-Mathisen, J.; Copenhagen, D.R.; Edwards, R.H. Molecular analysis of system $\mathrm{N}$ suggests novel physiological roles in nitrogen metabolism and synaptic transmission. Cell 1999, 99, 769-780. [CrossRef]

20. Jacobson, I.; Sandberg, M.; Hamberger, A. Mass transfer in brain dialysis devices-A new method for the estimation of extracellular amino acids concentration. J. Neurosci. Methods 1985, 15, 263-268. [CrossRef]

21. Kanamori, K.; Ross, B.D. Quantitative determination of extracellular glutamine concentration in rat brain, and its elevation in vivo by system A transport inhibitor, alpha-(methylamino)isobutyrate. J. Neurochem. 2004, 90, 203-210. [CrossRef] [PubMed] 
22. Dolgodilina, E.; Imobersteg, S.; Laczko, E.; Welt, T.; Verrey, F.; Makrides, V. Brain interstitial fluid glutamine homeostasis is controlled by blood-brain barrier SLC7A5/LAT1 amino acid transporter. J. Cereb. Blood Flow Metab. 2016, 36, 1929-1941. [CrossRef] [PubMed]

23. Gu, S.; Roderick, H.L.; Camacho, P.; Jiang, J.X. Identification and characterization of an amino acid transporter expressed differentially in liver. Proc. Natl. Acad. Sci. USA 2000, 97, 3230-3235. [CrossRef] [PubMed]

24. Chan, K.; Busque, S.M.; Sailer, M.; Stoeger, C.; Broer, S.; Daniel, H.; Rubio-Aliaga, I.; Wagner, C.A. Loss of function mutation of the Slc38a3 glutamine transporter reveals its critical role for amino acid metabolism in the liver, brain, and kidney. Pflugers Arch. 2016, 468, 213-227. [CrossRef] [PubMed]

25. Boulland, J.L.; Osen, K.K.; Levy, L.M.; Danbolt, N.C.; Edwards, R.H.; Storm-Mathisen, J.; Chaudhry, F.A. Cell-specific expression of the glutamine transporter SN1 suggests differences in dependence on the glutamine cycle. Eur. J. Neurosci. 2002, 15, 1615-1631. [CrossRef] [PubMed]

26. Boulland, J.L.; Rafiki, A.; Levy, L.M.; Storm-Mathisen, J.; Chaudhry, F.A. Highly differential expression of SN1, a bidirectional glutamine transporter, in astroglia and endothelium in the developing rat brain. Glia 2003, 41, 260-275. [CrossRef] [PubMed]

27. Robinson, M.B. Regulated trafficking of neurotransmitter transporters: Common notes but different melodies. J. Neurochem. 2002, 80, 1-11. [CrossRef] [PubMed]

28. Melikian, H.E. Neurotransmitter transporter trafficking: Endocytosis, recycling, and regulation. Pharmacol. Ther. 2004, 104, 17-27. [CrossRef] [PubMed]

29. Bermingham, D.P.; Blakely, R.D. Kinase-dependent Regulation of Monoamine Neurotransmitter Transporters. Pharmacol. Rev. 2016, 68, 888-953. [CrossRef] [PubMed]

30. Newton, A.C. Protein kinase C: Poised to signal. Am. J. Physiol. Endocrinol. Metab. 2010, 298 , E395-E402. [CrossRef] [PubMed]

31. Shimohama, S.; Saitoh, T.; Gage, F.H. Changes in protein kinase C isozymes in the rat hippocampal formation following hippocampal lesion. Hippocampus 1993, 3, 43-55. [CrossRef] [PubMed]

32. Chen, S.; Hillman, D.E. Immunohistochemical localization of protein kinase C delta during postnatal development of the cerebellum. Brain Res. Dev. Brain Res. 1994, 80, 19-25. [CrossRef]

33. Masliah, E.; Cole, G.; Shimohama, S.; Hansen, L.; DeTeresa, R.; Terry, R.D.; Saitoh, T. Differential involvement of protein kinase C isozymes in Alzheimer's disease. J. Neurosci. 1990, 10, 2113-2124. [PubMed]

34. Barmack, N.H.; Qian, Z.; Yoshimura, J. Regional and cellular distribution of protein kinase C in rat cerebellar Purkinje cells. J. Comp. Neurol. 2000, 427, 235-254. [CrossRef]

35. Todo, T.; Shitara, N.; Nakamura, H.; Takakura, K.; Tomonaga, M.; Ikeda, K. Astrocytic localization of the immunoreactivity for protein kinase C isozyme (type III) in human brain. Brain Res. 1990, 517, 351-353. [CrossRef]

36. Porter, J.T.; McCarthy, K.D. Astrocytic neurotransmitter receptors in situ and in vivo. Prog. Neurobiol. 1997, 51, 439-455. [CrossRef]

37. Balkrishna, S.; Broer, A.; Kingsland, A.; Broer, S. Rapid downregulation of the rat glutamine transporter SNAT3 by a caveolin-dependent trafficking mechanism in Xenopus laevis oocytes. Am. J. Physiol. Cell Physiol. 2010, 299, C1047-C1057. [CrossRef] [PubMed]

38. Nissen-Meyer, L.S.; Popescu, M.C.; Hamdani el, H.; Chaudhry, F.A. Protein kinase C-mediated phosphorylation of a single serine residue on the rat glial glutamine transporter SN1 governs its membrane trafficking. J. Neurosci. 2011, 31, 6565-6575. [CrossRef] [PubMed]

39. Sidoryk-Wegrzynowicz, M.; Lee, E.; Mingwei, N.; Aschner, M. Disruption of astrocytic glutamine turnover by manganese is mediated by the protein kinase C pathway. Glia 2011, 59, 1732-1743. [CrossRef] [PubMed]

40. Nissen-Meyer, L.S.; Chaudhry, F.A. Protein Kinase C Phosphorylates the System N Glutamine Transporter SN1 (Slc38a3) and Regulates Its Membrane Trafficking and Degradation. Front. Endocrinol. 2013, 4, 138. [CrossRef] [PubMed]

41. Reyland, M.E. Protein kinase C isoforms: Multi-functional regulators of cell life and death. Front. Biosci. 2009, 14, 2386-2399. [CrossRef]

42. Benzil, D.L.; Finkelstein, S.D.; Epstein, M.H.; Finch, P.W. Expression pattern of alpha-protein kinase C in human astrocytomas indicates a role in malignant progression. Cancer Res. 1992, 52, 2951-2956. [PubMed]

43. Yoshimura, S.; Sakai, H.; Nakashima, S.; Nozawa, Y.; Shinoda, J.; Sakai, N.; Yamada, H. Differential expression of Rho family GTP-binding proteins and protein kinase C isozymes during C6 glial cell differentiation. Brain Res. Mol. Brain Res. 1997, 45, 90-98. [CrossRef] 
44. Masliah, E.; Yoshida, K.; Shimohama, S.; Gage, F.H.; Saitoh, T. Differential expression of protein kinase C isozymes in rat glial cell cultures. Brain Res. 1991, 549, 106-111. [CrossRef]

45. Brodie, C.; Kuperstein, I.; Acs, P.; Blumberg, P.M. Differential role of specific PKC isoforms in the proliferation of glial cells and the expression of the astrocytic markers GFAP and glutamine synthetase. Brain Res. Mol. Brain Res. 1998, 56, 108-117. [CrossRef]

46. Schneggenburger, R.; Forsythe, I.D. The calyx of Held. Cell Tissue Res. 2006, 326, 311-337. [CrossRef] [PubMed]

47. Renden, R.; Taschenberger, H.; Puente, N.; Rusakov, D.A.; Duvoisin, R.; Wang, L.Y.; Lehre, K.P.; von Gersdorff, H. Glutamate transporter studies reveal the pruning of metabotropic glutamate receptors and absence of AMPA receptor desensitization at mature calyx of Held synapses. J. Neurosci. 2005, 25, 8482-8497. [CrossRef] [PubMed]

48. Uwechue, N.M.; Marx, M.C.; Chevy, Q.; Billups, B. Activation of glutamate transport evokes rapid glutamine release from perisynaptic astrocytes. J. Physiol. 2012, 590, 2317-2331. [CrossRef] [PubMed]

49. Kirischuk, S.; Heja, L.; Kardos, J.; Billups, B. Astrocyte sodium signaling and the regulation of neurotransmission. Glia 2016, 64, 1655-1666. [CrossRef] [PubMed]

50. Mizuno, K.; Noda, K.; Ueda, Y.; Hanaki, H.; Saido, T.C.; Ikuta, T.; Kuroki, T.; Tamaoki, T.; Hirai, S.; Osada, S.; et al. UCN-01, an anti-tumor drug, is a selective inhibitor of the conventional PKC subfamily. FEBS Lett. 1995, 359, 259-261. [CrossRef]

51. Cahoy, J.D.; Emery, B.; Kaushal, A.; Foo, L.C.; Zamanian, J.L.; Christopherson, K.S.; Xing, Y.; Lubischer, J.L.; Krieg, P.A.; Krupenko, S.A.; et al. A transcriptome database for astrocytes, neurons, and oligodendrocytes: A new resource for understanding brain development and function. J. Neurosci. 2008, 28, 264-278. [CrossRef] [PubMed]

52. Boehmer, C.; Okur, F.; Setiawan, I.; Broer, S.; Lang, F. Properties and regulation of glutamine transporter SN1 by protein kinases SGK and PKB. Biochem. Biophys. Res. Commun. 2003, 306, 156-162. [CrossRef]

53. Sidoryk-Wegrzynowicz, M.; Lee, E.S.; Ni, M.; Aschner, M. Manganese-induced downregulation of astroglial glutamine transporter SNAT3 involves ubiquitin-mediated proteolytic system. Glia 2010, 58, 1905-1912. [CrossRef] [PubMed]

54. Daniels, G.M.; Amara, S.G. Regulated trafficking of the human dopamine transporter. Clathrin-mediated internalization and lysosomal degradation in response to phorbol esters. J. Biol. Chem. 1999, 274, 35794-35801. [CrossRef] [PubMed]

55. Melikian, H.E.; Buckley, K.M. Membrane trafficking regulates the activity of the human dopamine transporter. J. Neurosci. 1999, 19, 7699-7710. [PubMed]

56. Apparsundaram, S.; Schroeter, S.; Giovanetti, E.; Blakely, R.D. Acute regulation of norepinephrine transport: II. PKC-modulated surface expression of human norepinephrine transporter proteins. J. Pharmacol. Exp. Ther. 1998, 287, 744-751. [PubMed]

57. Jayanthi, L.D.; Samuvel, D.J.; Ramamoorthy, S. Regulated internalization and phosphorylation of the native norepinephrine transporter in response to phorbol esters. Evidence for localization in lipid rafts and lipid raft-mediated internalization. J. Biol. Chem. 2004, 279, 19315-19326. [CrossRef] [PubMed]

58. Qian, Y.; Galli, A.; Ramamoorthy, S.; Risso, S.; DeFelice, L.J.; Blakely, R.D. Protein kinase C activation regulates human serotonin transporters in HEK-293 cells via altered cell surface expression. J. Neurosci. 1997, 17, 45-57. [PubMed]

59. Geerlings, A.; Lopez-Corcuera, B.; Aragon, C. Characterization of the interactions between the glycine transporters GLYT1 and GLYT2 and the SNARE protein syntaxin 1A. FEBS Lett. 2000, 470, 51-54. [CrossRef]

60. Fornes, A.; Nunez, E.; Alonso-Torres, P.; Aragon, C.; Lopez-Corcuera, B. Trafficking properties and activity regulation of the neuronal glycine transporter GLYT2 by protein kinase C. Biochem. J. 2008, 412, 495-506. [CrossRef] [PubMed]

61. Beckman, M.L.; Bernstein, E.M.; Quick, M.W. Multiple G protein-coupled receptors initiate protein kinase C redistribution of GABA transporters in hippocampal neurons. J. Neurosci. 1999, 19, RC9. [PubMed]

62. Bode, B.P.; Reuter, N.; Conroy, J.L.; Souba, W.W. Protein kinase C regulates nutrient uptake and growth in hepatoma cells. Surgery 1998, 124, 260-268. [CrossRef]

63. Kalandadze, A.; Wu, Y.; Robinson, M.B. Protein kinase C activation decreases cell surface expression of the GLT-1 subtype of glutamate transporter. Requirement of a carboxyl-terminal domain and partial dependence on serine 486. J. Biol. Chem. 2002, 277, 45741-45750. [CrossRef] [PubMed] 
64. Gonzalez, M.I.; Ortega, A. Regulation of the $\mathrm{Na}^{+}$-dependent high affinity glutamate/aspartate transporter in cultured Bergmann glia by phorbol esters. J. Neurosci. Res. 1997, 50, 585-590. [CrossRef]

65. Barrera, S.P.; Castrejon-Tellez, V.; Trinidad, M.; Robles-Escajeda, E.; Vargas-Medrano, J.; Varela-Ramirez, A.; Miranda, M. PKC-Dependent GlyT1 Ubiquitination Occurs Independent of Phosphorylation: Inespecificity in Lysine Selection for Ubiquitination. PLoS ONE 2015, 10, e0138897. [CrossRef] [PubMed]

66. De Juan-Sanz, J.; Nunez, E.; Lopez-Corcuera, B.; Aragon, C. Constitutive endocytosis and turnover of the neuronal glycine transporter GlyT2 is dependent on ubiquitination of a C-terminal lysine cluster. PLoS ONE 2013, 8, e58863. [CrossRef] [PubMed]

67. Sheldon, A.L.; Gonzalez, M.I.; Krizman-Genda, E.N.; Susarla, B.T.; Robinson, M.B. Ubiquitination-mediated internalization and degradation of the astroglial glutamate transporter, GLT-1. Neurochem. Int. 2008, 53, 296-308. [CrossRef] [PubMed]

68. Gonzalez-Gonzalez, I.M.; Garcia-Tardon, N.; Gimenez, C.; Zafra, F. PKC-dependent endocytosis of the GLT1 glutamate transporter depends on ubiquitylation of lysines located in a C-terminal cluster. Glia 2008, 56, 963-974. [CrossRef] [PubMed]

69. Sorkina, T.; Miranda, M.; Dionne, K.R.; Hoover, B.R.; Zahniser, N.R.; Sorkin, A. RNA interference screen reveals an essential role of Nedd4-2 in dopamine transporter ubiquitination and endocytosis. J. Neurosci. 2006, 26, 8195-8205. [CrossRef] [PubMed]

70. Garcia-Tardon, N.; Gonzalez-Gonzalez, I.M.; Martinez-Villarreal, J.; Fernandez-Sanchez, E.; Gimenez, C.; Zafra, F. Protein kinase C (PKC)-promoted endocytosis of glutamate transporter GLT-1 requires ubiquitin ligase Nedd4-2-dependent ubiquitination but not phosphorylation. J. Biol. Chem. 2012, 287, 19177-19187. [CrossRef] [PubMed]

71. Boehmer, C.; Palmada, M.; Rajamanickam, J.; Schniepp, R.; Amara, S.; Lang, F. Post-translational regulation of EAAT2 function by co-expressed ubiquitin ligase Nedd4-2 is impacted by SGK kinases. J. Neurochem. 2006, 97, 911-921. [CrossRef] [PubMed]

72. Susarla, B.T.; Robinson, M.B. Internalization and degradation of the glutamate transporter GLT-1 in response to phorbol ester. Neurochem. Int. 2008, 52, 709-722. [CrossRef] [PubMed]

73. Yan, X.; Yadav, R.; Gao, M.; Weng, H.R. Interleukin-1 beta enhances endocytosis of glial glutamate transporters in the spinal dorsal horn through activating protein kinase C. Glia 2014, 62, 1093-1109. [CrossRef] [PubMed]

74. Chen, T.; Tanaka, M.; Wang, Y.; Sha, S.; Furuya, K.; Chen, L.; Sokabe, M. Neurosteroid dehydroepiandrosterone enhances activity and trafficking of astrocytic GLT-1 via sigma1 receptor-mediated PKC activation in the hippocampal dentate gyrus of rats. Glia 2017, 65, 1491-1503. [CrossRef] [PubMed]

75. Deken, S.L.; Wang, D.; Quick, M.W. Plasma membrane GABA transporters reside on distinct vesicles and undergo rapid regulated recycling. J. Neurosci. 2003, 23, 1563-1568. [PubMed]

76. Chaudhry, F.A.; Lehre, K.P.; van Lookeren Campagne, M.; Ottersen, O.P.; Danbolt, N.C.; Storm-Mathisen, J. Glutamate transporters in glial plasma membranes: Highly differentiated localizations revealed by quantitative ultrastructural immunocytochemistry. Neuron 1995, 15, 711-720. [CrossRef]

77. Martinez-Lozada, Z.; Guillem, A.M.; Flores-Mendez, M.; Hernandez-Kelly, L.C.; Vela, C.; Meza, E.; Zepeda, R.C.; Caba, M.; Rodriguez, A.; Ortega, A. GLAST/EAAT1-induced glutamine release via SNAT3 in Bergmann glial cells: Evidence of a functional and physical coupling. J. Neurochem. 2013, 125, 545-554. [CrossRef] [PubMed]

78. Tzingounis, A.V.; Wadiche, J.I. Glutamate transporters: Confining runaway excitation by shaping synaptic transmission. Nat. Rev. Neurosci. 2007, 8, 935-947. [CrossRef] [PubMed]

79. Willoughby, D.; Thomas, R.C.; Schwiening, C.J. Comparison of simultaneous pH measurements made with 8-hydroxypyrene-1,3,6-trisulphonic acid (HPTS) and pH-sensitive microelectrodes in snail neurones. Pflugers Arch. 1998, 436, 615-622. [CrossRef] [PubMed]

80. Balkrishna, S. Molecular Insights into the Regulation of Glutamine Transport across Cellular Membranes. Ph.D. Thesis, The Australian National University, Canberra, Australia, 2013. Available online: http:/ /ibrary. anu.edu.au/record=b3120904 (accessed on 12 January 2018).

(C) 2018 by the authors. Licensee MDPI, Basel, Switzerland. This article is an open access article distributed under the terms and conditions of the Creative Commons Attribution (CC BY) license (http:/ / creativecommons.org/licenses/by/4.0/). 